\title{
粉体のレオロジー評価と流動性に関する考察
}

\author{
平村 行慶*
}

\section{Consideration between Evaluation of Powder Rheology and Flowability}

Yukiyoshi Hiramura*

Received 30 March 2017; Accepted 26 July 2017

\begin{abstract}
This study evaluates how powders are affected by air using Powder Rheometer which can measure the torque for powder viscosity and flow energy. It can be challenging to directly evaluate the properties of an aerated powder, as glass beads and MCC only require a small amount of air to change their behavior, but flour may require significantly more, or will be insensitive to aeration. The aeration characteristics of a powder can be studied with powder rheology by measuring their flow energy during aeration. This evaluation demonstrates how it is possible to evaluate the flow characteristics of powder using different aeration regimes.
\end{abstract}

Keywords: Powder rheometer, Aerated powder, Powder viscosity, BFE, Aerated energy.

\section{1. 緒言}

粉体は固体粒子の集合体である。粒子はその大きさや 形状，表面状態など，さまざまな違いがあり，それらが 粉体の特徵に大きく影響する。さらに粒子間の空間や粒 子内の空隙に気体や液体が存在するため, 粉体流動性に 関する評価には多種多様な手法が用いられる。それらは 大きく静的な手法と動的な手法に分けることができる。

静的な手法としては安息角測定が一般的である。安息 角の評価には複数の手法が存在する。外力により生じた 安息角を測定する手法もある。しかしどの手法において も測定時の粉体は安定した状態を評価するため, 安息角 測定は静的な手法と大別することができる。安息角測定 は粉体の安定に関する特徴については, 解りやすく簡単 な操作で測定できる。しかし，実際に粉体を取り扱う各 種工程では粉体の流動に関する障害が多く，安定に関す る特徵だけでは流動時の障害ついて明確な結果を得られ ないこともある。

静的な流動性評価を補う評価として，粒子に着目した 評価が用いられることがある。粉体の流動時には, 粒子 と粒子の衝突や空間の増減などが繰り返し起こる。この とき, 粒子の大きさや形状, 表面状態の違いなどにより 粉体流動性は大きく変化する。遠藤らの研究[1]では, 安

スペクトリス株式会社 マルバーン事業部

（ T 650-0047 兵庫県神戸市中央区港島南町 5-5-2 神戸国際ビジネ スセンター北館 511)

Malvern Instruments A division of Spectris Co., Ltd.

(North Building 511 KIBC, 5-5-2, Minatojimaminami-machi, Chuo-

ku, Kobe, Hyogo 650-0047, Japan)

* Corresponding Author yukiyoshi.hiramura@malvern.com
息角の評価に粒子形状が大きく影響することが報じられ ている。粒子の大きさや形状は粒子径分布や画像解析で, 表面積や空隙は比表面積や細孔分布から評価されるのが 一般的である。その他の違いについてもそれぞれ個別の 手法が用いられる。これらの評価は, 粉体流動性に関す る結果を与えるが, 安息角測定と比べると時間や手間が 掛かる。

動的な流動性評価では粉体を一定の単位で実際に流動 させて測定する。このときの流動状態は, 評価される粉 体が実際に取り扱われる状態に近いことが望ましい。例 えば配管輸送時の詰まりやスクリューフィーダーへの付 着, ホッパーからの取り出し, 流動層での乾燥や造粒な どである。実工程に近い状態で評価できる点が動的な流 動性評価の最大の特徵である。

動的な流動性評価はこれまでにも多くの施設で用いら れ, それらをまとめた研究もいくつか発表されている。 中嶋らの研究[2]では粉体中の空間率を容器底部からの通 気により制御し, 粉体の流動特性をレオロジー的な解析 で評価している。また, 永島らの研究[3]ではさまざまな 微粉体に対する動的な流動性評価により, Geldart's Classification との比較が行なわれている。

今回の研究では粉体流動性についてレオロジー解析と 動的な流動性評価によって得られた流動エネルギーの解 析を比較した。レオロジー解析は流動層や擋拌翼の設計 などに用いられる既知の解析方法である。両者の比較か ら, 簡易な操作である流動エネルギーの解析がレオロジー 解析と同様の傾向を得られることを確認し, 評価方法と して測定者の負担軽減に有用であることを示す。 


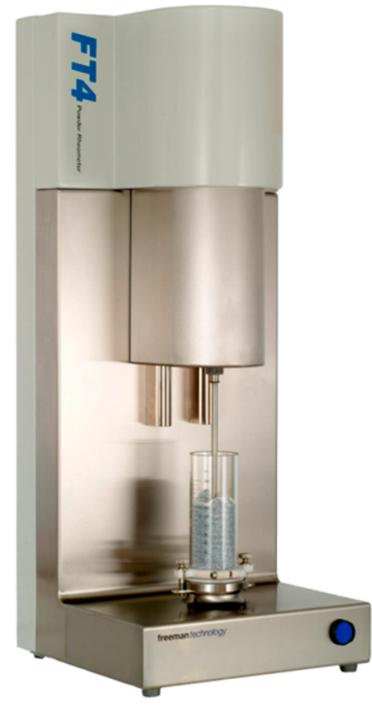

Fig. 1 Powder Rheometer FT4

\section{2. 実験方法}

\section{1 評価装置}

本評価では動的な流動性評価ができることおよび，粉 体に通気を施しながら測定できる装置として，Fig. 1 の Powder Rheometer FT4（Freeman Technology 社製，以下 FT4）を用いた。

測定は粉体が充填された容器に測定用ブレード（以下 ブレード）を一定の翼先端速度で回転させながら進入さ せ，装置底部のロードセルにより垂直応力を，上部卜ル ク計により回転トルクを測定する。このとき，垂直応力 $F$, 回転トルク $T$ およびブレード高さからブレードが粉 体中を移動する際に要したエネルギーを算出する。ブレー ド半径を $R$, ブレード先端が移動する螺旋角度を $\alpha$ とす ると，ブレード高さに応じたブレードの移動エネルギー は $[T /(R \tan \alpha)+F]$ で求められる。今回の評価は, 容器内径 $50 \mathrm{~mm}$, 測定容積 $160 \mathrm{~mL}$, ブレード翼径 $48 \mathrm{~mm}$, 螺旋角 度 50 で実施した。粉体層への通気にはFT4 用の Aeration Control Unit（以下 ACU）を用いた。ACU は測定容器底 部より流量を制御した空気を流すことが可能である。ま た，通気時に発生した圧力を記録することも可能である。

\section{2 評価試料}

試料には市販品であるガラスビーズ，小麦粉，微結晶 セルロースを用いた。試料の粒子径・粒子形状に関する 詳細を Table 1 に示す。またそれらの粒度分布を Fig. 2 (a), (b) に, 粒子画像を Fig. 3 に示す。粒子径と粒子形状 は乾式分散型画像解析装置 Morphologi G3SE（Malvern Instruments 社製）を用いて測定した。

Fig. 1 (a)，(b) 抢よび Table 1 より今回使用した試料は, 体積基準粒子径分布の 50\%粒子径（以下 Dv50）が概㸚近 く，個数基準粒子径分布の $50 \%$ 粒子径（以下 Dn $50 ）$ は 大きく異なる。Dv50 と Dn50 が大きく異なる試料は粉体 中に微粉が多いと考えられる。また粒子形状もそれぞれ 異なる傾向が確認できる。
Table 1 Sample size and shape

\begin{tabular}{lcccc}
\hline Sample & \multicolumn{2}{c}{$\begin{array}{c}\text { CE Diameter } \\
{[\mu \mathrm{m}]}\end{array}$} & $\begin{array}{c}\text { Circularity } \\
{[-]}\end{array}$ & $\begin{array}{c}\text { Aspect Ratio } \\
{[-]}\end{array}$ \\
& Dn50 & Dv50 & Mean & Mean \\
\hline Glass Beads & 67 & 69 & 0.986 & 0.951 \\
Flour & 13 & 69 & 0.909 & 0.727 \\
MCC & 15 & 82 & 0.843 & 0.582 \\
\hline
\end{tabular}

\section{3 測定領域の確定}

予備実験として $500 \mathrm{~mL} / \mathrm{min}$ で通気したガラスビーズに 対し，時計回りでブレードを進入させ，ブレード高さに 対するトルク值の変化を確認した。このとき，ブレード の翼先端速度を 4 段階に変更し測定した。それぞれの翼 先端速度から以下の計算式 Eq. (1) より Shear Rate を算出 し, 得られたトルク值と粉体中のブレード高さの関係を Fig. 4 に示す。ここで $\gamma$ は Shear Rate $\left[\mathrm{s}^{-1}\right], D$ はブレード 直径 $[\mathrm{m}], \omega$ は角速度 $[\mathrm{rad} / \mathrm{s}]$ を示す。

$$
\gamma=\frac{(D / 2) 2 \pi \omega}{\pi D}
$$

Fig. 4 の結果より, 測定時のブレード高さに対するトル ク值は上層 $50 \mathrm{~mm} \sim 80 \mathrm{~mm}$ で最大值/最小值はおよそ 30 〜 50 倍, 中層 $30 \mathrm{~mm} \sim 50 \mathrm{~mm}$ でおよそ 1.1 倍, 下層 $0 \mathrm{~mm}$ 〜30 mm で㧍よそ 1.1 倍と変化した。中層から下層にか けてのトルク值は安定していたが, 下層は容器底面近く, 通気流量によっては不安定となる可能性があるため, 今 回の評価では中層でのトルク值の平均を用いてレオロ ジー解析を行なった。上層でトルク值が安定しなかった 理由は，通気による粉体表面のバブリングと考えられる。

\section{4 評価方法}

予備実験の結果から, 測定容器の中層に対して, Table 2 の条件で各種粉体についてのトルク值を測定した。得 られたトルク值から測定領域全体での平均卜ルク值を算 出し，以降のレオロジー解析に用いた。

\section{5 粘度の算出}

以下の計算式 Eq. (2) により測定範囲から得られた平均 トルク值と角速度から粘度を算出する。ここで $\eta$ は粉体 粘度 $[\mathrm{Pa} \cdot \mathrm{s}], A$ は装置定数 $\left[\mathrm{rad} / \mathrm{cm}^{3}\right], T$ は平均トルク值 $[\mathrm{N} \cdot \mathrm{m}]$ を示す。装置定数は 1.19 を採用した。

$$
\eta=A \cdot \frac{T}{\omega}
$$

\section{3. 実験結果および考察}

\section{1 かさ密度が異なる粉体の粘度評価結果}

各種試料粉体に対し通気流量を変えてトルク值を測定 した。本実験では通気後に測定用ブレードを用いて粉体 のかき混ぜを実施し, その後測定容器を分割することで 測定時の粉体体積を $160 \mathrm{~mL}$ に統一している。これによ り測定に用いた粉体のかさ密度は粉体質量を $160 \mathrm{~mL}$ で 除することで算出可能である。この測定の結果を Fig. 5 (a)〜 (c) に示す。またそれぞれの通気流量とかさ密度を

Table 3 に示す。 


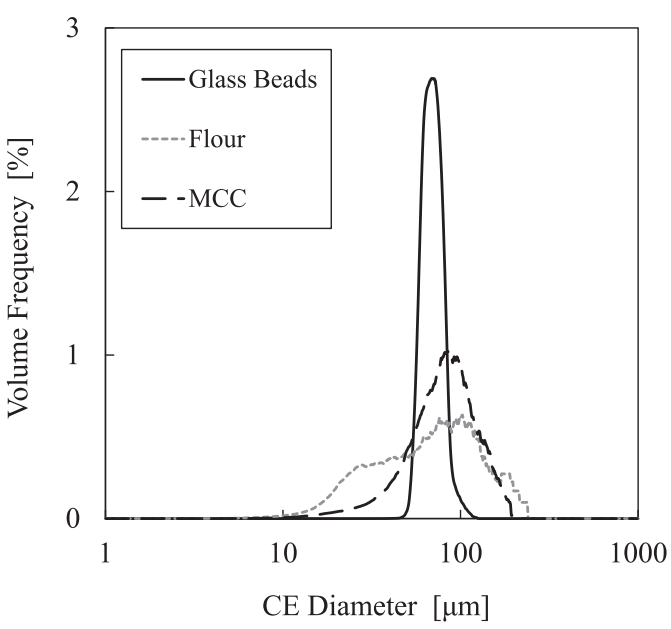

(a) Volume distribution

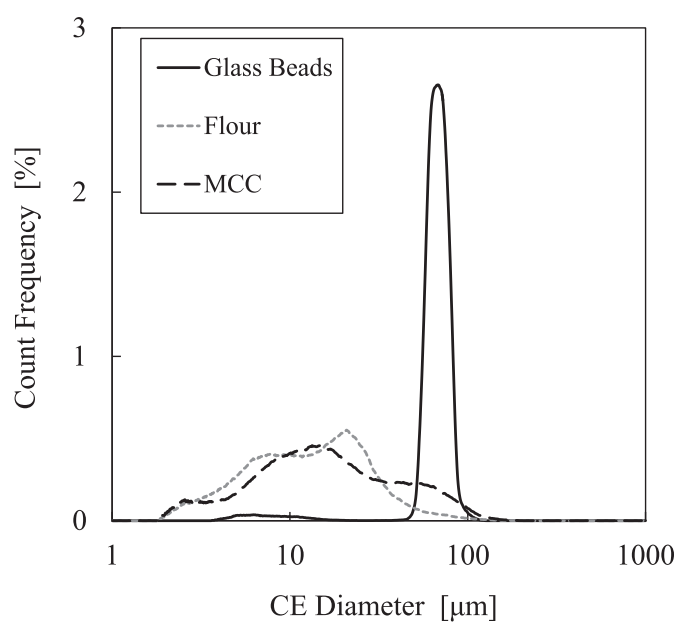

(b) Number distribution

Fig. 2 Particle size distribution of CE Diameter

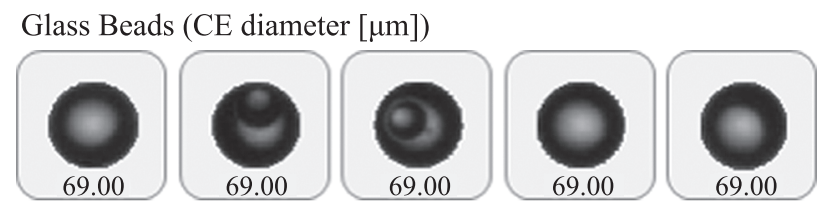

Flour $(\mathrm{CE}$ diameter $[\mu \mathrm{m}])$

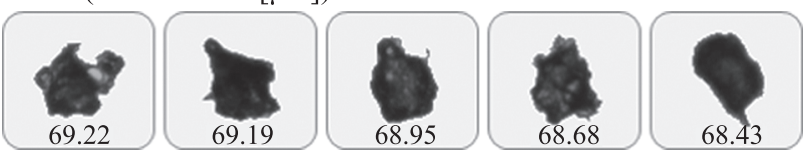

$\operatorname{MCC}(\mathrm{CE}$ diameter $[\mu \mathrm{m}])$

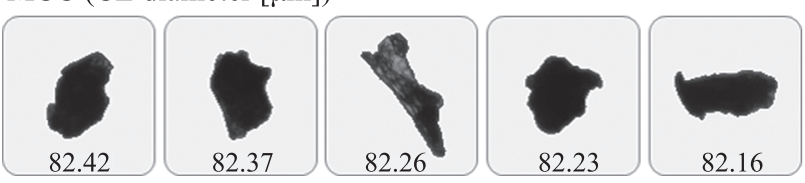

Fig. 3 Test particles

Fig. 5 (a) よりガラスビーズは通気なしでは他の粉体よ りも粘度が高いことが確認できる。これは測定に用いて いる測定值がトルクのみであるため，使用した粉体の質 量が大きく影響していると考えられる。ただ， Shear Rate が大きくなると粘度は大幅に低下する傾向も確認できる。 また，通気によりかさ密度が小さくなると粘度も大きく 低下し, 強い通気下では粘度は 0 付近まで下がる。Fig. 5 (b) では Shear Rate に対する小麦粉の粘度は, ガラスビー ズのように変化しないことが確認できる。また，通気に よりかさ密度を小さくしても粘度は 0 付近までは下がら ないことも確認できる。Fig. 5 (c) の微結晶セルロースも 小麦粉と同様の傾向であるが，通気によりかさ密度が小 さくなると粘度が 0 付近まで下がることが小麦粉と異な る。

今回の評価は測定時の通気流量を Table 3 のように設 定して実施した。小麦粉は流動化に要する通気流量が他 よりも多く，通気による流動化が起こりにくいと考えら れる。その要因としてDn50が他よりも小さく，付着性 が強いためと推察できる。しかし，Dn50 が小さい微結晶 セルロースはガラスビーズと同程度に流動化するため,

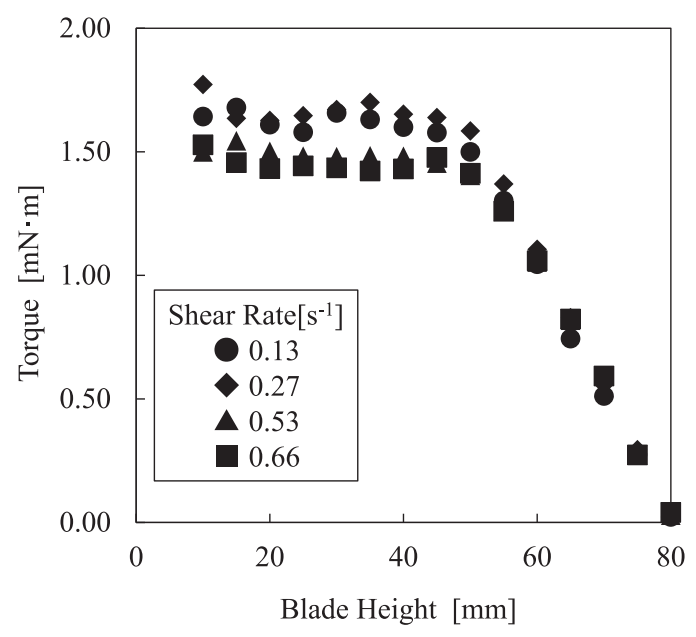

Fig. 4 Relationship between torque and blade height for different shear rate of glass beads

Table 2 Measurement conditions

\begin{tabular}{lcc} 
Test Zone of Height & {$[\mathrm{mm}]$} & $30-50$ \\
Blade Tip Speed & {$\left[\mathrm{mm} \cdot \mathrm{s}^{-1}\right]$} & $20,40,80,100$ \\
Shear Rate & {$\left[\mathrm{s}^{-1}\right]$} & $0.13,0.27,0.53,0.66$ \\
\hline
\end{tabular}




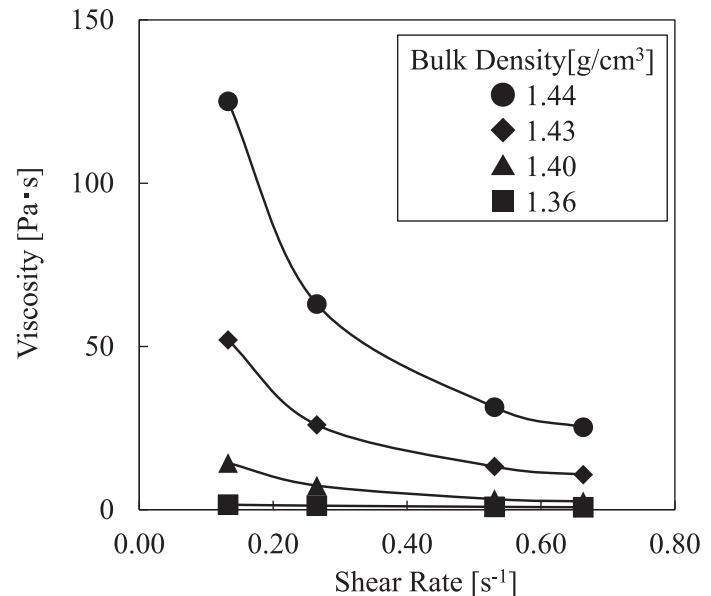

(a) Glass beads

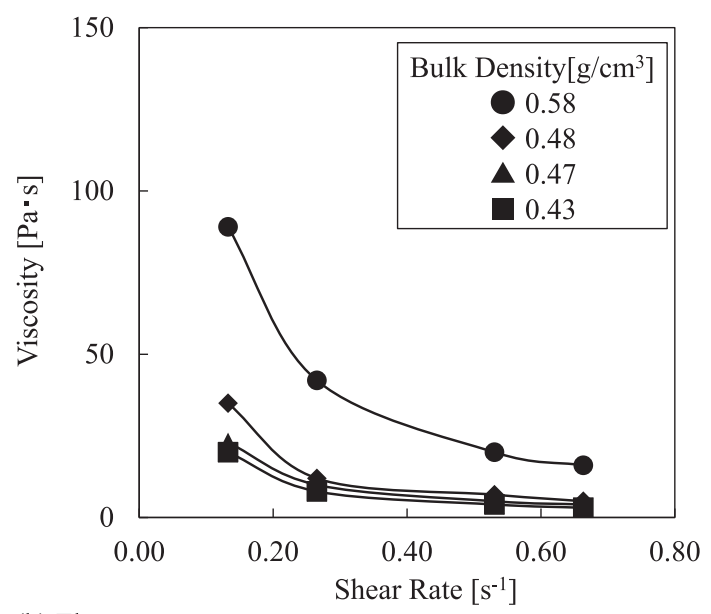

(b) Flour

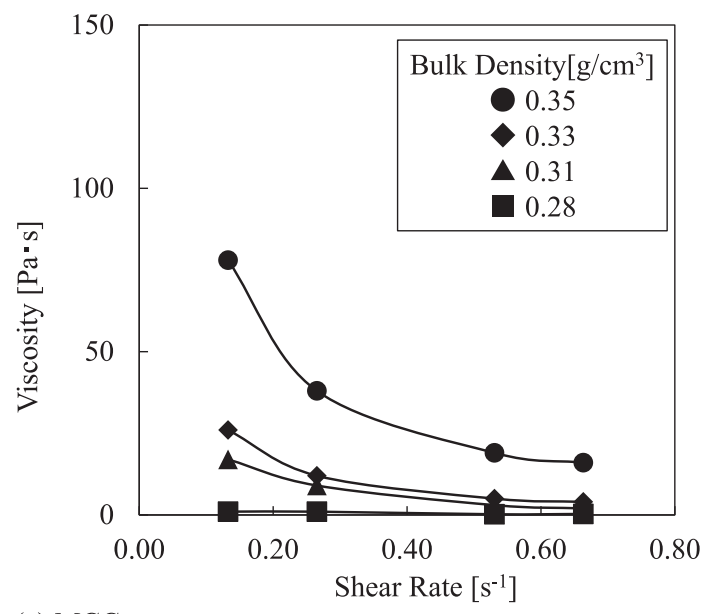

(c) MCC

Fig. 5 Relationship between viscosity and shear rate for different bulk density of glass beads, flour and MCC

流動化の違いを粒子径だけで予測することは難しいと考 えられる。

\section{2 各種粉体の粘度評価結果}

各種粉体に対する Shear Rate と粘度の関係を Fig. 6 に 示す。比較する通気速度はどの粉体に対しても十分な流

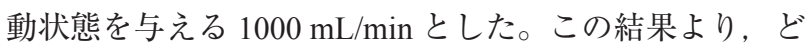
の試料も Shear Rate が大きくなることで粉体粘度が減少
Table 3 Air flow rate and bulk density

\begin{tabular}{ccccc}
\hline & & \multicolumn{3}{c}{ Bulk Density $\left[\mathrm{g} / \mathrm{cm}^{3}\right]$} \\
\cline { 3 - 5 } & & Glass Beads & Flour & MCC \\
\hline \multirow{2}{*}{ Air Flow Rate $[\mathrm{mL} / \mathrm{min}]$} & 0 & 1.44 & 0.58 & 0.35 \\
& 250 & 1.43 & - & 0.33 \\
& 500 & 1.40 & - & 0.31 \\
& 1000 & 1.36 & 0.48 & 0.28 \\
& 2000 & - & 0.47 & - \\
& 4000 & - & 0.43 & - \\
\hline
\end{tabular}

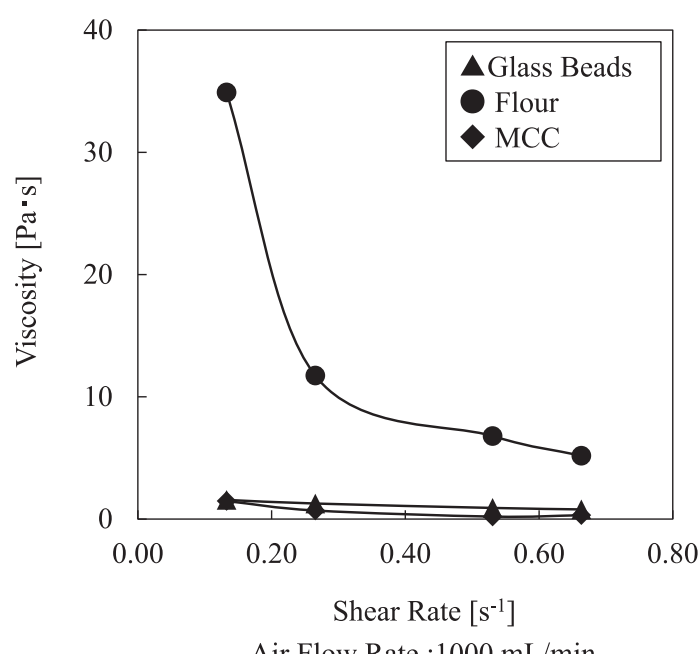

Fig. 6 Relationship between viscosity and shear rate for aerated powders

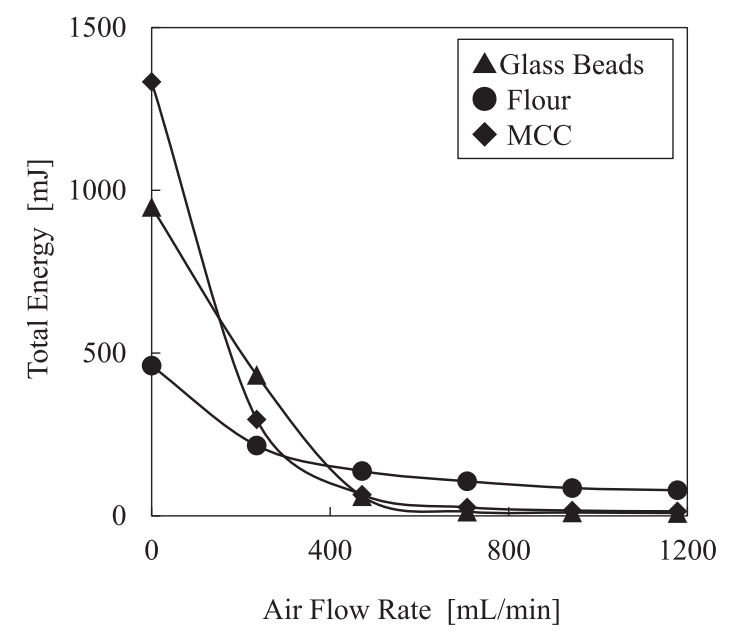

Fig. 7 Effect of air flow rate on total energy for different powders

する傾向が確認できる。ガラスビーズと微結晶セルロー スは粘度がほぼ 0 付近となり, 通気によって流体のよう に変化していることがわかる。また, 小麦粉は他の試料 よりも粘度が高いが, Shear Rate により大きく変化する ため, 実工程で取り扱う際には Shear Rate の選択が流動 性に大きく影響すると考えられる。

\section{3 通気時流動エネルギーの測定結果}

FT4 の通気試験による通気流量と流動エネルギーにつ いての結果を Fig. 7 と Table 4 に示す。また, 通気流量と ACU で検出した圧力の関係を Fig. 8 に示す。 


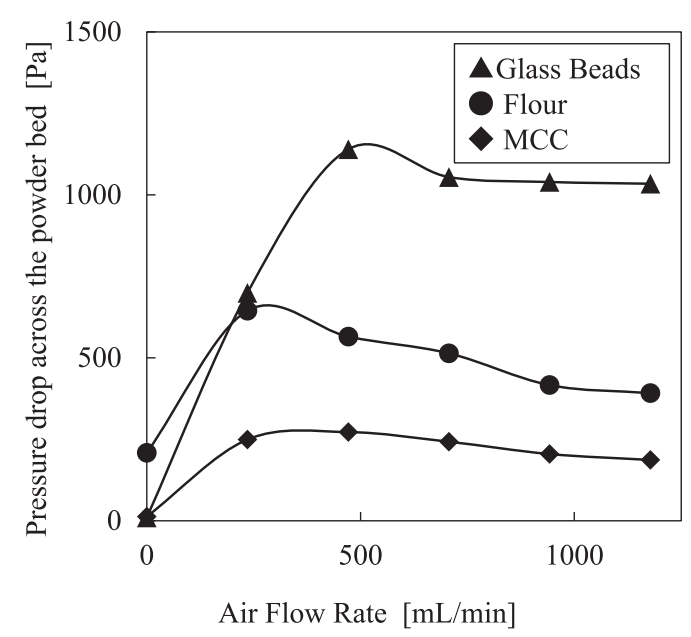

Fig. 8 Effect of air flow rate on air pressure for different powders

Table 4 Result of dynamic flow energy test

\begin{tabular}{lccc}
\hline & BFE $[\mathrm{mJ}]$ & AE $[\mathrm{mJ}]$ & AR $[-]$ \\
\hline Glass Beads & 949 & 9 & 109 \\
Flour & 461 & 79 & 6 \\
MCC & 1333 & 14 & 96 \\
\hline
\end{tabular}

$B F E$ は通気していない粉体中のブレードの移動エネル ギーを示す。 $A E$ は最大通気流量でのブレードの移動エネ ルギーを示し, $A R$ は $B F E$ を $A E$ で除した值である。こ こで, $A R$ はガラスビーズと微結晶セルロースでほぼ近い
值となり，粘度の評価と同様に非常に流動化しやすい傾 向が確認できる。また, 小麦粉は他の粉体と比較して $A R$ が小さく，流動化しにくいことが確認できる。さらに， 微結晶セルロースの $B F E$ が最も大きいことから, 通気の 影響がなければ流動性が悪いことも確認できる。かさ密 度はガラスビーズょりも小さく, 粉体の付着性に影響し やすい微粉量は粒子径分布の結果から小麦粉に近いため, この差異は粒子形状に関係すると推察できる。

Fig. 8 に示す測定中の圧力変化では, どの粉体も流動 化までに圧力が上昇し, $1000 \mathrm{~mL} / \mathrm{min}$ では圧力も低下し, 十分に通気ができていることが確認できる。この結果か ら圧力が最大となる通気速度は最小流動化速度に近いと 考えられるため, FT4 の通気試験から実工程で有効な通 気流速を予測することが可能である。

\section{4. 結言}

今回の評価では粉体に通気を施した際の流動化を，レ オロジー解析と流動エネルギー解析の両面で測定した。 どちらの解析でも小麦粉が流動化しにくく, ガラスビー ズや微結晶セルロースが流動化しやすいものとなった。 そのため, レオロジー解析と流動エネルギー解析は同様 の結果を得ることができる評価方法と考えられる。実工 程に近い測定条件で粉体の流動化について評価すること が可能と考えられる。また, 粒子径や粒子形状などの単 一なパラメータだけでは流動化に関する予測が難しいこ とも今回の評価結果より確認できた。

\section{Nomenclature}

$A \quad$ : apparatus constant

$A E$ : aerated energy

$A R$ : aeration ratio

$B F E$ : basic flowability energy

$D$ : diameter of blade

Dn50: $50 \%$ of particle size in number distribution

Dv50: $50 \%$ of particle size in volume distribution

$\begin{array}{rll}{\left[\mathrm{rad} / \mathrm{m}^{3}\right]} & F & : \text { force } \\ {[\mathrm{J}]} & R & : \text { radius of blade } \\ {[-]} & T & : \text { torque } \\ {[\mathrm{J}]} & \alpha & : \text { helix } \\ {[\mathrm{m}]} & \gamma & : \text { shear rate } \\ {[\mathrm{m}]} & \eta & : \text { viscosity } \\ {[\mathrm{m}]} & \omega & : \text { angular velocity }\end{array}$
$[\mathrm{rad} / \mathrm{s}]$

\section{References}

[1] S. Endoh, H. Endoh, J. Koga, Mokushitsufuntai no keijou to ansokukaku ni oyobosu sono eikyou, J. Soc. Powder Technol., Japan, 22 (1985) 765-768.

[2] K. Nakashima, Y. Komoda, H. Suzuki, H. Usuie, Evaluation of powder rheology in a gas-solid suspending system, J. Soc.
Powder Technol., Japan, 44 (2007) 4-9.

[3] H. Nagashima, T. Ishikura: Identification of flow properties of fine powders based on dynamic flow characteristics obtained by stirring and aerating, J. Soc. Powder Technol., Japan, 52 (2015) 576-584. 